\title{
Noticias dadas por Tomás Gage, a propósito del Teatro en España, México y Guatemala (1624-1637)
}

\author{
La representación de una comedia de Lope de Vega, \\ habladurias relativas a la famosa actriz Amarilis \\ $y$ producciones de indios $y$ criollos ${ }^{1}$
}

\begin{abstract}
TOMAS Gage, segundo hijo de Juan Gage y de su esposa Margarita Copley - conocidos recusantes católicos y fervientes sostenedores en Inglaterra de la Compañia de Jesús-, nació hacia el año de 1600. Siguió a su hermano mayor Enrique al colegio jesuíta de San Omer, donde no sobresalió como estudiante. En 1620 pasó de San Omer al colegio inglés en Valladolid, España, con el fin de terminar sus estudios. Allí él y sus condiscípulos se enredaron en las disputas políticas suscitadas entre el rector inglés y los jesuítas españoles. Descontento del sistema y de la disciplina de la Orden, se decidió a unirse a los dominicos, paso que desagradó mucho a su padre, quien esperaba verle miembro de la Compañía de Jesús. ${ }^{2}$ Desatento a las amonestaciones paternas --Tomás Gage nos lo revela-, en 1624 ya estaba hospedado en el convento dominico en Jerez. ${ }^{3}$ En mayo del mismo año se presentó allí un comisario del Papa, autorizado a alistar frailes para la misión que iba organizándose para las Filipinas. Aunque se prohibía que los ingleses pasasen a las Indias Españolas, Gage, persuadido por su amigo Antonio Meléndez, se resolvió a tomar parte en la expedición. Pasados cinco años en España, ya hablabá bien el castellano y entendía bien el carácter y la vida españoles. Escondido en un barril, para no ser visto por las autoridades, logró
\end{abstract}


estar a bordo de un navío cuando la flota se hizo a la vela y así tuvo ocasión de partir para el Nuevo Mundo.

Tomás Gage, en su relación titulada $A$ New Survey of the WestIndias or the English American, his Travail by Sea and Land, 1648, ${ }^{4}$ no se limitó a contar la historia de su vida y sus propias aventuras en México y Centro América y el Mar del Sur, sino que escribió una obra notable por sus penetrantes observaciones sobre la civilización y cultura de los criollos e indios. Entreveró relatos míticos con acontecimientos reales, inclusive los sucesos recientes de la conquista. La primera narración auténtica y detallada en inglés sobre las tierras comprendidas en el Virreinato de Nueva España, contiene una minuciosa descripción de la ciudad de México, con muchos datos sobre su aspecto antes del sitio por Hernán Cortés, las costumbres de sus habitantes, tanto peninsulares como criollos, mestizos, esclavos, etc. Al autor le interesó todo: el sistema de gobierno, político y eclesiástico; el comercio; la geografía de las tierras que atravesó yendo a la ciudad de Guatemala; la vida social de los nativos; los idiomas indígenas; las supersticiones y leyendas indias; las bebidas (especialmente el chocolate); las habladurías relativas a personas de distinción; las escuelas; las fiestas; las recreaciones, etc. Después de servir de cura en Guatemala, decidido a volver a Inglaterra, hizo un viaje por tierra hasta Nicaragua y de allí continuó su camino por tierra y agua, teniendo muchas aventuras peligrosas hasta llegar a Panamá. Regresó a Inglaterra a fines de 1637, después de una ausencia de unos veinte años.

En la flota de cuarenta y un buques en que viajaban los veintisiete frailes dominicos, de cuyo grupo Gage formaba parte, los treinta padres jesuítas también enviados de misioneros a las Filipinas y los veinticuatro frailes mercedarios que iban con destino a México, había varios personajes insignes: el Marqués de Cerralvo, quien iba de Virrey de Nueva España, con su esposa ; don Martín Carrillo, inquisidor del Santo Oficio de Valladolid, nombrado visitador general de México; don Juan Niño de Toledo, enviado para asumir la presidencia de Manila. ${ }^{5}$ En una compañía compuesta de tantos religiosos, era natural que hiciesen todo lo posible para celebrar con pompa el día consagrado a sus santos patrones y, por consiguiente, en esos días cantaban himnos, disparaban cohetes y en la fiesta de Santo Domingo 
aun fué representada una comedia de Lope de Vega, con los papeles desempeñados por jóvenes religiosos, soldados y pasajeros:

E1 último día de julio, siendo para la Compañía de Jesús, y por decreto de Roma, la fiesta de San Ignacio, patrón y fundador de su orden, los treinta jesuítas a bordo del navio Santa Gertrudis, en honot de su santo, dieron al resto de la flota un brillante espectáculo. Desde la víspera, el velero apareció ataviado de lienzo blanco; entre sus pabellones y juanetes mayores, algunos ostentaban las armas jesuítas, otros la efigie del propio Ignacio. Esa noche fueron disparados por lo menos cincuenta cañonazos, además de cuatrocientos o quinientos cohetes. Estaba bonancible el tiempo. Todos los mástiles y jarcias del buque se hallaban adornados de faroles de papel con las luces encendidas. En toda la noche no dejaton los músicos de tocar ni los españoles de cantar. Las diversiones del siguiente día eran asimismo grandes, los jesuitas aumentando el placer de los españoles con una procesión general en el navio, cantando'sus himnos y antífonas en honor de su supuesto santo, y todo esto secundado con ruidosas salvas de artillería, no siendo economizada la pólvora para completar el gusto y triunfo. El 4 de agosto, siendo el día que Roma consagra a Santo Domingo, primer fundador de la orden dominica o de los predicadores, el buque en que yo viajaba, el San Antonio, intentó sobrepujar al Santa Gertrudis, con la ayuda de los veintisiete religiosos que en él se encontraban. Todo fué efectuado de noche y de día, como antes en el Santa Gertrudis, con pólvora, cohetes, luminarias, músicos y canciones. El regocijo y el triunfo de los dominicos excedieron aun al de los jesuitas en el festín opulento de pescado y carne a que convidaron a todos los de la Compañía de Jesús, a Don Juan Niño de Toledo, presidente de Manila, y al capitán del Santa Gettrudis. Terminada la comida, para la diversión de la tarde tuvieron preparada una comedia del famoso Lope de Vega, cuyos papeles fueron hechos por algunos soldados, pasajeros y frailes jóvenes. Confieso que fué ejecutada la representación con tanta dignidad y buenas decoraciones en el estrecho recinto de nuestro buque como pudiera haberse hecho en el mejor escenario de la corte de Madrid. Acabada la comedia y servida una colación de confituras para poner fin al regocijo del día, nuestra chalupa y la del Santa Gertrudis llevaron a nuestros convidados a su navío, despidiéndonos al son de nuestros músicos y principales cañones. ${ }^{6}$

Llegados los navios a San Juan de Ulúa, México, el día 12 de septiembre de 1624, toda la población se dirigió al desembarcadero a recibir al nuevo virrey, a quien, bajo palio y portando sus cruces, condujeron en procesión a la catedral los padres y canónigos en 
compañía de los frailes de las varias órdenes religiosas. Celebrada una solemne misa, el alcalde mayor, el ayuntamiento, unos jueces enviados de la capital y todos los soldados de la flota y el pueblo acompañaron luego al virrey a su hospedaje. ${ }^{7}$ Revela Gage que al día siguiente, o sea el 13 , fueron los padres dominicos por la mañana a despedirse de sus nuevos amigos " $y$ después de la comida fueron puestos asientos en la catedral para que nos sentásemos y viésemos representar una comedia que a propósito había sido estudiada y preparada por el pueblo para el entretenimiento del nuevo virrey de México". 8

Respecto a las artes enseñadas por las monjas en la ciudad de México, observa Gage:

Los caballeros y vecinos envían sus hijas a ser criadas en estos conventos donde se les enseña a hacer toda suerte de conservas y confituras, toda clase de obras de aguja, toda clase de música, la que es tan exquisita en esa ciudad que me atrevo a afirmar que el pueblo es atraído a sus iglesias más por el deleite de oír la música que por tomar placer en el servicio de Dios. Además, enseñan a estas niñas a representar piezas dramáticas $y$. para atraer la gente a sus iglesias, las hacen recitar, ataviadas ricamente de hombres y mujeres, breves diálogos en sus coros, especialmente el día de San Juan y los ocho días antes de la Navidad. Se representan tan galantemente que ha habido muchas refriegas facciosas $y$ contiendas individuales, $y$ habia algunas en mi tiempo, por disputar cuál de estos conventos sobresalia en la música y en la educación de las niñas. ${ }^{9}$

Chiapa de los Indios, uno de los pueblos de aborígenes más populosos de toda América (tenía a lo menos cuatro mil familias), gozaba de ciertos privilegios otorgados por el rey de España, entre los cuales estaba el de nombrar a su propio gobernador indio. Allí vivían muchos dones orgullosos de su sangre india, algunos de los cuales rivalizaban con los caballeros españoles en su ostentación y pompa y en sus fiestas. ${ }^{10}$ "Esta villa está situada a orillas de un gran río, donde se hallan muchas barcas y canoas, en las cuales se ha enseñado a los indios a representar con mucha destreza combates navales, y a actuar de Ninfas del Parnaso, Neptuno, Eolo y el resto de las divinidades paganas, con admiración de todo su pueblo. Ellos sitian con sus barcas la villa, luchando con bravura, como si se hubiesen entrenado toda su vida en batallas marítimas hasta obligarla a rendirse." 11 Estos eran también diestros en las corridas de toros, 
en los juegos de cañas, en las carreras de caballos, en los bailes españoles, en la música, etc. Construían torres y castillos de madera y lienzo pintado, de los cuales fingían a las mil maravillas una batalla con cohetes, dardas y otros fuegos artificiales. ${ }^{12}$ "Respecto al representar obras dramáticas, esto es una parte regular de sus solemnes pasatiempos. Son tan generosos, cuando hay festejos, que no limitan los gastos de banquetes y confituras para los frailes y los pueblos vecinos." 13

Gage, en camino de la capital de la Capitanía General de Guatemala, pasó por Chimaltenango, pueblo habitado por muchos indios ricos que comerciaban en la vecindad. Su iglesia era igual a las mejores de la ciudad de Guatemala (llamada hoy día la Antigua) y en la música superaba a casi todas las del país. ${ }^{14}$ "La fiesta principal de Chimaltenango cae en el 26 de julio, el día consagrado a Santa Ana, y se celebra con la feria más rica de toda clase de mercancías que jamás yo haya visto en esas regiones. Además, añaden a los festejos las corridas de toros, carreras de caballos, reptesentaciones de piezas dramáticas, mascaradas, bailes y música, todo esto hecho con bizarría por los indios del pueblo." 15

Por casualidad, conoció Gage en la ciudad de Guatemala a un fraile franciscano llamado Juan Navarro, quien, después de haber gozado durante un año en España y con vestido secular la compañia impúdica de Amarilis, ${ }^{16}$ famosa actriz, por temor de que se averiguase su modo de vida, se alistó en 1632 en una misión destinada a Guatemala, esperando disirutar allí, con más libertad y menos miedo de castigo, de la vida lasciva y carnal. ${ }^{17}$

Notó nuestro autor que se celebraban en el Virreinato de Nueva España y la Capitanía General de Guatemala todas las fiestas religiosas del año. En la víspera de la Navidad solía organizarse una danza de pastores que iban a medianoche a la iglesia a ofrecer una oveja y a comenzar su baile delante del Belén que reproducía en detalle la escena de la cuadra en que la Virgen dió a luz a Jesucristo. También había danzas de personas vestidas de ángeles con alas. ${ }^{18}$ El día de los Reyes no sólo los indios sino los alcaldes, jueces y otros oficiales acudían a la iglesia a ofrendar sus regalos. ${ }^{19}$

Varios cronistas de México y Guatemala escribieron sobre la gran afición que sentían los nativos por la danza y las representaciones dramáticas, practicadas desde muchos años antes de la conquista. ${ }^{20}$ Por medio de dichos pasatiempos los padres y frailes de la 
iglesia inculcaban la fe, contaban episodios bíblicos, retrataban a los santos y ayudaban en la evangelización de la población india. No había en las Indias ningún pueblo que no estuviese dedicado a la Virgen o a algún santo. Dos o tres meses antes de la fiesta del santo patrón, toda la población indígena se reunia de noche para practicar las danzas que se acostumbraba tener en los festejos. Para cada danza habia un maestro que la enseñaba a los demás. En esas reuniones bebían gran cantidad de chocolate y chicha y perturbaban la paz de la noche con sus canciones, gritos, golpes sobre conchas y música instrumental. Llegada la fiesta, bailaban en público por espacio de ocho dias las danzas preparadas en secreto. Estas empezaban en la iglesia, delante de la imagen del santo, o en el atrio, y de allí, durante los ocho días de fiesta los participantes pasaban de casa en casa, bebiendo chocolate o chicha. ${ }^{21}$ En la danza llamada toncontín, se vestian los danzantes de blanco, con los jubones y calzones de lienzo, la cabeza y el cuerpo adornados con penachos de plumas; se producía la sorda y pesada armonía con un instrumento llamado tepanabaz y se cantaban canciones en loor de algún santo. Tenían otro baile de movimiento mucho más rápido en que fingían ser fieras o aves de rapiña que iban cazando hombres o bestias. También era costumbre dar una tragedia "en forma de danza, a fin de representar la crucifixión de San Pedro y el degüello de San Juan Bautista. ${ }^{22}$ En cuanto al aparato, se exigía lujo en los vestidos de los que hacían los papeles de reyes y reinas. Los actores, que desempeñaban los papeles de los dos santos vestían un manto largo, mientras los demás se disfrazaban de capitanes y soldados con armas. Necesitábase una cabeza pintada que, colocada sobre un plato, simulaba la del Bautista, y, además, una cruz de la que colgaban al que actuaba de San Pedro.

La danza principal ejecutada entre ellos se llama toncontin, que algunos españoles, que babian vivido en las Indias, bailaron ante el rey de España en la corte de Madrid para mostrarle algunas de las costumbres de los aborígenes y se dijo haber agradado muchísimo al rey. Asi se baila: en los pueblos grandes participan por lo común treinta o cuarenta indios y menos en los pueblos pequeños. Los danzantes se visten de blanco, tanto los jubones como los calzones de lienzo y ayates o toallas, que de un lado casi llegan a tocar la tierra. Sus calzones y ayates se adornan con bordados de seda o con pájaros o se orlan de algún encaje. Algunos consiguen jubones y calzones y ayates de seda, todos alquilados expresamente para estas ocasiones. 23 Sobre la espalda 
cuelgan largos penachos de plumas de todo color, los que se pegan a un pequeño bastidor, dorado por la parte de fuera y becho expresamente para este uso; se ata este bastidor con cintas a los hombros para que no se suelte con el movimiento del cuerpo y caiga a la tierra. Sobre la cabeza llevan otro penacho de plumas menos grande, atado al sombrero o a algún casco, dorado o pintado, o a algún yelmo. En la mano llevan también un abanico de plumas y la mayoría tiene en los pies plumas juntadas como en alas cortas de pájaros; algunos usan zapatos, otros no. Asi están casi cubiertos de plumas de color.

La música y armonía de esta danza son sólo las que se hacen de un tronco de árbol hueco, redondeado y bien raido por dentro y por fuera, muy pulido y reluciente, unas cuatro veces más grueso que nuestros violones, con dos o tres hendeduras grandes en el lado de arriba y algunos agujeros en la extremidad. Este instrumento se llama tepanabaz. En este leño, que se coloca sobre un banco o asiento largo en medio de los indios, pega el maestro del baile con dos palitos arrollados de lana en la extremidad, que se cubre de un cuero dado con pez, para que no se pierda la lana. Con golpes en este instrumento, que produce sonidos sordos y pesados pero algo ruidosos, él da a los bailadores sus varios tonos, cambios y señales para el movimiento del cuerpo, o derecho o inclinado, y les advierte qué y cuándo han de cantar. Así bailan, llevando el compás y circulan alrededor de ese instrumento, uno siguiendo al otro, algunas veces derecho, otras dando vueltas completas o medias, algunas veces inclinando el cuerpo, de modo que las plumas que llevan en las manos casi tocan la tierra, y cantando la vida de su santo o la de algún otro. Toda esta danza no es más que una manera de andar en círculo, que continuarán haciendo por dos o tres horas enteras en un lugar y de alli irán a hacer lo mismo a otra casa. Sólo el jefey los señores principales del pueblo bailan este toncontín, que exa el viejo baile que practicaban antes de conocer el cristianismo, excepto que, en vez de cantar la vida de los santos, cantaban alabanzas a sus dioses paganos.

Tienen otra clase de baile, muy practicado, que es una especie: de caza de alguna fiera, que antes en el tiempo de su gentilidad habia de sacrificarse a sus dioses y que en la actualidad ofrendan al santo. Este baile tiene una gran variedad de tonos con urs: pequeño tepanabaz y muchas conchas de tortuga, o en vez de ellas. ollas cubiertas de cuero, sobre las cuales pegan como sobre ell tepanabaz, y acompañado con flautas. En este baile gritan mucho y hacen gtan ruido, dándose voces los unos a los ottos y hablándose como en una pieza dramática, algunos narrando una cosa, otros otra relativa a la bestia que cazan. Unos bailadores están vestidos de fieras, con pieles pintadas en forma de león, tigre, lobo y en la cabeza una reproducción de la cabeza de tales 
bestias, mientras que los otros la llevan adornada con reproducciones de la del águila o de alguna otra ave de rapiña. En las manos tienen algunos palos pintados, alabardas, espadas y hachas con los cuales amenazan matar la bestia que buscan. Otros, en lugar de perseguir una bestia, cazan un hombre, como si las fieras en un yermo buscasen un hombte para darle la muerte. Este hombre que es asi cazado ha de ser muy ligero y ágil, como quien corre para salvar la vida, pegando aquí y allí para defenderse de las bestias, que al fin le cogen y devoran. Como el toncontín consiste en su mayor parte en andar y dar vueltas e inclinar despacio el cuerpo, así este baile consiste enteramente en la acción, en correr algunas veces en un círculo y otras veces fuera, en saltar y pegar con los instrumentos que tienen en la mano. Este es un juego muy grosero y lleno de chillidos y ruido horrendo en que no me deleité nunca, 24

Hay otro baile mexicano que practican, algunos vestidos de hombres, otros de mujeres. En el tiempo pagano, lo usaban para cantar alabanzas a su rey o emperador, pero ahora aplican sus canciones al Rey de la Gloria o al sacramento, recitando estas palabras $\mathrm{u}$ otras análogas con alguna variedad en las alabanzas:

Salid mexicanas, bailad toncontin:

Cantad 25 las galanas en cuetpo gentil.

$Y$ se repite:

Salid mexicanas, bailad toncontin:

Al Rey de la Gloria tenemos aquí.

Asì van en círculo bailando, tocando sus guitarras muy bien en algunos lugares, repitiendo todos juntos de vez en cuando uno o dos versos, y llamando a las mexicanas a salir con el manto galano para cantar alabanzas al Rey de la Gloria. Además de éstas, tienen y practican nuestras danzas moriscas y las de los negros, con sonajas 26 en las manos, las que se hacen de una colección de campanillas moriscas, con que producen una variedad de sonidos que marcan el compás para los pies ligeros.

Pero la danza que atrae y pasma a la gente es una tragedia representada en forma de baile, con el tema de la muerte de San Pedro o el degüello de San Juan Bautista. En estas danzas hay an emperador o un rey Herodes con sus reinas ataviadas lujosamente y alguna otra persona, con un manto largo y amplio, que representa a San Pedro o a San Juan Bautista, quien, mientras los demás danzan, anda en medio con un libro en la mano, como diciendo sus oraciones. El resto de los danzantes van disfrazados de capitanes $y$ soldados con espada, daga $\circ$ alabarda en la mano. Bailan al compás de un tamborcillo y flautas, algunas 
veces en círculo y otras hacia adelante, dialogan con el emperador o rey y entre sí discuten la aprehensión y ejecución del santo. $A$ veces, siéntanse rey y reina para escuchar las quejas contra el santo y la defensa de éste y, otras, bailan con los demás. Finaliza la danza con la crucifixión, cabeza abajo, de San Pedro o con la degollación del Bautista, teniendo dispuesta en un plato una cabeza pintada, que regalan a los reyes. Regocijados, todos vuelven a danzar y así concluyen, bajando de la cruz al que desempeñó el papel de San Pedro. Los indios que participan en esta danza tienen temerosa superstición de lo que hacen, como si la acción que representan hubiera sido cometida realmente. Cuando yo vivía entre ellos, no era raro que quien en la danza habia de actuar de San Pedro o San Juan Bautista fuese primero a confesarse, diciendo que era preciso ser santo y puro como el representado, $y$, por consiguiente, estar preparado para la muerte. $Y$ asimismo quien había hecho el papel de Herodes o Herodías, y algunos de los soldados que habian acusado a los santos, venían después a confesar su pecado y pedir absolución por su crimen. 27

\author{
HARVEY L. Johnson, \\ Northrvestern University, \\ Evanston, Illinois.
}

\title{
NOTAS
}

1 Una beca del American Council of Learned Societies de Washington, D. C., me permitió viajar durante el verano de 1942 por México y Guatemala, donde reuní parte de los materiales utilizados en este estudio.

2 Thomas Gage, The English American, A New Survey of the West Indies, 1648, edited with an introduction by $A$. P. Newton (The Broadway Travellers), London, 1928 , págs. xii-xiii.

3 Gage da a entender que corría el año 1625 en vez de 1624, indudablemente por falta de memoria. Es preciso que sea el año 1624 , porque en la flota en que atravesó el océano, viajaban, como él mismo afirma, el Marqués de Cerralvo, nuevo virrey de Nueva España, y don Martín Carrillo, inquisidor del Santo Oficio de Valladolid, quienes hicieron su entrada en la ciudad de México el 3 de noviembre de 1624. Véase Andrés Cavo, Los tres siglos de México dutante el gobierno español, con notas y suplemento por Carlos María de Bustamante, México, 1836, I, 276; Vicente Riva Palacio, México a través de los siglos, Barcelona, sin fecha, II, 583; Batonesa Serrano de Wilson, México $y$ sus gobernantes de 1519 a 1910, Barcelona, [1910], I, 119. A. P. Newton, editor y autor de la introducción de la edición del año 1928 (citada en la nota 2), no reparó en ese error de Gage.

4 Para este trabajo me valí de la segunda edición que lleva el título A New Survey of the West-Indias ot The English American his Ttavail by Sea 
and Land, imptesa por E. Cotes y vendida por John Sweeting, London, 1655. Tanto la teciente edición inglesa de 1928, citada arriba en la nota 2 , como la versión española con el título Nueva relación que contiene los viajes de Tomás Gage en la Nueva España (traducción al español de la versión francesa de 1677 , hecha por M. de Carcavi), París, 1838, dos tomos, son muy incompletas; omiten muchos pasajes de interés, inclusive algunas digresiones que tratan del teatro en España y el Nuevo Mundo. También debe notarse que o el traductor de la edición francesa o el de la española no comprendió en todo caso el significado de algunas palabras de la obra original. En consecuencia, a mí me ha parecido más conveniente hacer una nueva traducción de las partes que uso, siempre consultando, donde los haya, los correspondientes pasajes de la traducción del año 1838 .

5 A New Survey of the West-Indias, etc., $2^{\text {a }}$ edicion, London, 1655 , pág. 15. Don Rodrigo Pacheco y Osorio. Marqués de Cerralvo, décimoquinto virrey de Nueva España, y don Martín Carrillo, inquisidor de Valladolid, 1legaron a México con amplios poderes para investigar las causas de la discordia entre el ex virrey Carrillo y el arzobispo Pérez de Laserna y castigar a los que habían robado los muebles y puesto fuego al palacio. Véase Serrano de Wilson, op. cit., 1, 113-119.

6 A New Survey of the West-Indias, etc., pág. 16. El profesor Irving A. Leonard tomó nota de la representación de la comedia de Lope en la cubierta del San Antonio en su interesante estudio titulado "Notes on Lope de Vega's Works in the Spanish Indies", Hispanic Review, 1938, VI, 287.

7 A New Survey of the West-Indias, etc., págs. 22-23.

8 lbid., pág. 24.

9 Ibid., pág. 59.

10 Ibid., pág. 104.

11 lbid., pág. 104.

12 Ibid., pág. 104. Los indios de Guatemala se dedicaban también a tepresentar batallas de pantomima. En la fiesta del Volcán conmemoraban la rebelión, en el año 1526 , contra el gobierno español, instigada por Sinacam, rey "de esta parte de Cachiquel, acompañado y coligado con Sequechul, tey de Utatlán y el Quiché". Para la fiesta "el alcalde corregidor del Valle, con los otros comisarios de reales fiestas, da la orden a los pueblos destinados para esta función; y estos pueblos, en obsequio de la real persona, a quien todos debidamente obedecemos, forman en la plaza mayor de esta ciudad (sitio y anfiteatro de representaciones lucidas), hacia la parte donde está la fuente, un volcán muy eminente de maderos fortísimos y muy robustos y crecidos, y la víspera de la representación le visten y adornan como un monte natural, con muchas hierbas y flores diversísimas (de que este país es muy abundante); después de adornado en esta forma acomodan en las ramas muchos monos, guacamayos, chocoyos, ardillas $y$ otros animalillos $y$, en algunas grutas que en él fingen, acomodan tres - cuatro dantas, según las que han podido cazar, ciervos, jabalies, y pizotes... 
Luego empiezan a entrar por las dos bocacalles que llaman de Mercaderes, y la de la Sala de Armas, muchas tropas (que formarán el número de mil) de indios desnudos con sus maztlates y embijados, a la usanza de la gentilidad de sus mayores, con plumas varias de guacamayos y pericos, con arcos y saetas despuntadas, otros con varas y rodelas a el estilo antiguo ... Después de éstos se siguen muchos diversos $\mathrm{y}$ incógnitos instrumentos $\mathrm{y}$ trompetas varias, que ordenan una confusión agradable, y a éstos siguen muchas danzas distintas, bien ordenadas y vistosas por la diversidad y costo de sus galas y muchos matices y cambiantes de lucidas plumas. A toda esta precedencia de autoridad festiva se sigue otra danza mayor en el número de los danzantes y riqueza y costo de sus galas, porque esta última viene con representación y aparato de mucha autoridad y grandeza, que se compone de los indios más ptincipales y ricos del pueblo de Jocotenango: síguese luego gran número de principales, vestidos a su usanza y traje del país, con ayates ricos, cadenas al cuello y sombreros con plumas; éstos sirven a el acompañamiento y séquito del gobernador de Jocotenango, que representa la persona del rey Sinacam. Le traen en hombros en una silla rica, dorada y muy adornada y compuesta de plumas de quetzal, con muchos abanicos y quitasoles que le siguen: él viene con gala y atavíos sobremanera ricos a su usanza, abanico de plumas en una mano, cetro en la otra, y corona ceñida, en que gasta y distribuye mucha suma de pesos... De esta manera y con esta autoridad y grandeza, entra por la plaza y se endereza y encamina a el volcán, adonde le suben en hombros hasta la casa de arriba, en representación de la retirada que el rey Sinacam hizo a la eminencia y bosque de aquel cerro de Quetzaltenango, que eta o es hacia el volcán de Tajumulco... Luego que se han introducido en esta grande y majestuosa plaza los indios tlaxcaltecos (sic) [descendientes de los que participaron en la campaña del año 1526], empiezan a combatir, acometiendo la fortaleza del volcán, formando sitio en torno de su circunvalación, disparando sus arcabuces y dando sus acometidas y asaltos por varias partes. Los defensores de él, disparando sus varas y saetas a el aire con muchos alaridos y voces, silbos y rumores confusos, hacen y representan muy al vivo la defensa de aquella fortaleza, ya uniéndose a una parte a resistir y defender los asaltos de tlaxcaltecos, adonde llama la ocasión. y ya volviéndose a esparcit y separar por el cuerpo de aquel fingido y recreable monte por diversos sitios y estancias, regidos y ordenados en estas ocasiones de sus capitanes y mandones, que se ven $y$ se conocen con diferencia de divisas, con plumas de quetzal y insignias de oro en las orejas como ministros reales. Dura esta contienda y debate mucho tiempo, con grande divertimiento y gusto de los mirones, hasta que, dando el último avance los tlaxcaltecos, los indios del volcán se van retrayendo y encimando, y los combatientes de la Ciudad Vieja repechándole, y encimándose los van retirando, y ellos como huyendo pasan de la otra parte del volcán; quedando de arte que el que representa a Sinacam queda casi solo prisionero de los tlaxcaltecos. Y, a este tiempo, el gobernador $y$ alcaldes de la Ciudad Vieja le sujetan a una cadena que llevan prevenida, y descendiendo del voicán vienen con él a palacio a presentarle rendido a el presidente: $y$, con esta ceremonia, vuelven a salir por donde entraron, y con el mismo compás $\mathrm{y}$ aparato $\mathrm{y}$, jugándose después tres o cuatro toros, se da término a la tarde." Véase Francisco Antonio de Fuentes y Guzmán, Recordación flotida, 
discurso historial y demostración natural, matetial, militar, y politica del Reyno: de Guatemala, Guatemala, 1932, I, 370-372.

13 A New Survey of the West-Indias, etc., pág. 104.

14 Ibid., pág. 116.

15 Ibid., pág. 117.

16 La famosa actriz Maria de Córdoba y de la Vega, conocida por los sobrenombres de Amarilis y la Gran Sultana, fué hija de Antonio Martínez y de Isabel de Córdoba y esposa del actor y empresario Andrés de la Vega. En 1617 hizo el papel de Doña Ana en Las paredes oyen, de Ruiz de Alarcón. En 1624 trabajaba en la compañía de su esposo cuando representaron el auto La sinagoga, de Claramonte y El Pastor lobo, atribuído a Lope de Vega. En el año siguiente tuvo parte en El Brasil restituido, también de Lope. En 1626 dirigió una compañía que representó ocho comedias en Aranjuez ante el rey. También representó su compañía Cautela contra cautela de Tirso de Molina. Todavía: trabajaba como actriz en 1643 y murió en Madrid en 1678, más de treinta años después de haberse retirado del escenario. Guillén de Castro y Francisco de Quevedo cantaron la belleza de esta actriz, "la mayor cómica que ahora se conoce", en las palabras de Alonso de Castillo Solórzano. A la cuenta, Amarilis tuvo intimas telaciones con el duque de Osuna, don Pedro Téllez Girón. Véase José Sánchez-Árjona, Noticias referentes a los anales del teatto en Sevilla desde Lope de Rueda hasta fines del siglo XVII, Sevilla, 1898, págs. 230-234; Hugo A. Rennert, The Spanish Stage in the Time of Lope de Vega, New York, 1909, págs. 456-457; Hugo A. Rennert y Américo Castro, Vida de Lope de Vega, Madrid, 1919, pág. 340.

17 A New Survey of the West-Indias, etc., pág. 8. Dicho fray Juan Navarro, nombrado maestro y lector en teología, llegó a ser muy estimado en la ciudad de Guatemala por su predicación ingeniosa. Enamoróse éste de una guatemalteca, cuyo esposo, volviendo inesperadamente a casa, la halló en brazos del fraile. Ciego de celos e ira, el marido, sacando la espada, cortó la cara e hirió en la cabeza al religioso, quien logró huir al jardin, y luego, volviéndose a su mujer, la mató con un golpe en la garganta. Navarro, expulsado del país, fué visto más tarde por nuestro cronista, mientras éste se hallaba en Cartagena de Nueva Granada. Navarro, el rostro marcado con cicatrices, estaba en camino a España. Ibid.s pág. 9.

18 Ibid., pág. 152. Como se sabe por esta descripción, no faltaban elementos dramáticos en la escena de la cuadta con sus bailes de pastores y ángeles. Tanto en España como en México se hacían dramatizaciones en torno a la liturgia de Navidad, apareciendo algunos pastores que iban a adorar al niño Jesús y ofrecerle sus dones. En la península fueron compuestos autos de Nacimiento por Gómez Manrique, Juan del Encina, Lucas Fernández, Torres Naharro, Hernán López de Yanguaz, Gil Vicente, etc. Véase J. P. Wickersham Crawford, The Spanish Pastoral Drama, Philadelphia, 1915, págs. 11-14, 21-23, 51, y Spanish Drama Before Lope de Vega, Philadelphia, 1922, passim; Angel Val- 
buena, Literatura dramática española, Barcelona, 1930, págs. 17-20, 29, 48, 55 . En el año 1596, en las lejanas misiones de la Sinaloa se celebró la Navjadad con un mitote, unos villancicos y motetes y la representación de un coloquio en la lengua regional. Véase José J. Rojas Garcidueñas, El teatro de Nueva España en el siglo XVI, México, 1935, pág. 53.

19 A New Survey of the West-Indias, etc., pág. 152.

20 Tenían los aztecas sus danzas sagradas y guerreras, dadas en honor de sus dioses. En algunas vestianse los participantes con la piel de las víctimas sacrificadas. Véase Toribio de Benavente o Motolinia, Historia de los Indios de la Nueva España, Barcelona, 1914, pág. 39. Con el correr de los años llegaron a ser entreveradas las danzas primitivas con farsas pantomímicas, diálogos himnos. Efectuábanse las danzas en terraplenes cuadrados, hallados a la entrada de los templos y mercados, en el patio de los templos, en las casas de los señores o en el palacio mismo de los reyes, que hacían todo lo posible para fomentat los ejercicios de música y drama. Véase Bernatdino de Sahagún, Histotia genetal de las cosas de Nueva España, México, 1938, I y II, passim, "Otros muchisinds pasatiempos tenía el rey Moteuhsoma, con que le regocijaban los del palaci, y aun toda la ciudad, que son muy buenos, largos y públicos, los cuales o los mandaba él hacer o venían los del pueblo a hacerle aquel servicio a su casa, y había un juego de esta manera: sobre la comida o banquete comenzaba nit baile general que ellos llaman netoteliztli, danza de regocijo y placer. Mucho antes de comenzarlo, tendían una gran estera en el patio de palacio, y encima ponían dos atabales, uno chico que llaman teponaztli, del tamaño de una vara y grueso, que es de una pieza de palo muy bien labrado por defuera y hueco, sin cuero ni pergamino; táñese con dos palillos que llaman olmaytli, que tíne al cabo liados unos bolillos con ulli, y con esto tocan el teponaztli: el otró es como los nuestros a manera de barril y alto, también tedondo y tamaño de vara y cuarta, hueco, entallado por fuera y pintado, y sobre la boca está puesto an parche o pergamino grueso de cuero de venado curtido, limpio, y está bien puesto y estirado, pues que apretado sube, y flojo baja el tono; táñese con tas manos sin palos, y es contrabajo. Estos dos atabales se tocan a la par, y llámanle huehuetl o sea tlapahuehuetl, y es tan concertado en el tocar que suena bien en toda la ciudad armonizado con voces. Aunque no las tienen buenas, cantan cantares alegres, regocijados y graciosos, o algún romance en loor de los reyes sus antepasados; contando en ellos las guerras, victorias, hazañas y otras cosas tales, y esto va todo en copla por sus consonantes, que suenan bien y placers. Cuando ya es tiempo de comenzar, silvan ocho o diez hombres muy recio, luego tocan los dichos atabales muy bajo, y no tardan a venir los bailadores con ricas mantas blancas, coloradas, verdes, amarillas y tejidas de diversisimos colores y labradas de lindas labores de flores, de caza y montería, y traen las manos ramilletes de rosas y flores, de muchisimas maneras o ventalles de pluma hermosa y oro y penachos verdes de plumas larguísimas de pabones de la tierra que dicen quetzalli, engastonadas en oro muy bien: muchos vienen con sus guirnaldas de lo mismo de mil géneros de rosas, que huelen con excelenciay muchos con papahigos de plumería o carátulas (o caretas), hechas como eabezas de águila, tigres, caimán y figuras de persona que traen sobre sus espaldas 
y otros animales fieros. Júntanse a este baile mil. dos mil y más bailadores, que cogen toda la plaza en redondo $y$, cuando menos cuatrocientos, $y$ son todos personas principales y aun señores, $\mathrm{y}$ cuanto mayor es $\mathrm{y}$ mejor cada uno, tanto más junto anda a los atabales. Bailan en corro de a tres de fondo cada escuadrón, trabados de las manos, una orden tras otras: guian dos, que son altos y diestros danzantes, y todos hacen y dicen lo que aquellos dos guiadores van haciendo, que si cantan ellos, responde todo el coro, unas veces mucho y otras poco, según el cantar o romance requiere, como en España y en todas partes. El compás que los dos llevan siguen todos, menos los de la postrera ringlera que por estar lejos y ser muchos, hacen dos entretanto que ellos uno, y cúmpleles meter más obra; pero a un mismo tiempo alzan o bajan los brazos, el cuerpo o la cabeza sola, y todo con no poca gracia, y con tanto concierto y sentido, que no discrepa uno de otro, de modo que se embebecen alli los hombres. A los príncipes cantan romances $y$ van despacio: tañen, cantan y bailan quedo, que parece todo gravedad; mas cuando se encienden, cantan villancicos y cantares alegres, avivase la danza y andan recio y aprisa, y, como dura mucho, a veces suelen beber vino o cacao molido, deshecho en unas copas hermosamente pintadas y decoradas, y con cada copa estos bailadores beben, y luego van a su danza y allí hay muchos escanciadores con sus copas para todos los que quisieren beber. También algunas veces andan allí como sobresalientes unos truhanes, contrahaciendo otras naciones en trage y en lenguage, y haciendo del borracho, loco - vieja que hacen reír y dan placer a la gente. Todos los que ban visto este baile dicen que es cosa graciosa y muy de ver, y mejor que la zambra de los moros que es la mejor danza que por acá sabemos, y si la hacen mugeres es muy mejor que la de hombres, y éstas la ejecutan forasteras y tlaxcaltecas, que las mexicanas no bailan tal baile públicamente, ni se ha visto tal que se haga así." Véase Francisco López de Gómara, Historia de la conquista de Hernando Cortés. México, 1826, I, 217-218. Con motivo de las fiestas en honor de Quetzalcoatl, se daban representaciones dramáticas en el patio del templo de Cholula dedicado a aquel dios. "Salían los representantes y hacian' entremeses, haciéndose sordos, arromadizados, cojos, ciegos y mancos, viniendo a pedir sanidad al idolo: los sordos respondiendo adefesios; y los arromadizados, tosiendo: los cojos cojeando decían sus miserias y quejas, con que hacían reír grandemente al pueblo. Otros salian en nombre de las sabandijas: unos vestidos como escarabajos, y otros como sapos, y otros como lagartijas, etc.; y encontrándose allí, referian sus oficios; y volviendo cada uno por sí, tocaban algunas flautillas, de que gustaban sumamente los oyentes, porque eran muy ingeniosas: fingían asimismo muchas mariposas y pájaros de muy diversos colores, sacando vestidos a los muchachos del templo en aquestas formas, los cuales, subiéndose en una arboleda que allí plantaban, los sacerdotes del templo les tiraban con cerbatanas, donde había en defensa de los unos y ofensa de los otros, graciosos dichos con que entretenian a los circunstantes; lo cual concluído hacían un mitote o baile con todos estos personajes, y se concluía la fiesta; y esto acostumbraban hacer en las principales fiestas." Véase Joseph de Acosta. Historia natural y motal de las Indias, Madrid, 1894, II, 135-136. Los cakchiqueles, en el territorio de Guatemala, tenían asimismo sus himnos, poemas y diálogos que se recitaban en los bailes como parte de sus ejercicios religiosos. Véase Daniel G. 
Brinton. The Annals of the Cakchiquels (Library of Aboriginal American Literature), Philadelphia, 1885, passim. En el Popol vuh o el libro del consejo se designan las danzas por nombres. "Al día siguiente se mostraron dos pobres, de lastimosos rostros, de lastimoso aspecto ... Hicieron poco, pero danzaron el buho, danzaron la comadreja, el armadillo, danzaron el ciempiés y los zancos." Véase El libto del consejo, traducción y notas de Georges Raynaud. J. M. González de Mendoza y Miguel Angel Asturias (Ediciones de la Universidad Nacional Autónoma), México, 1939, pág. 92. "E1 mayor y más aplaudido regocijo que en el tiempo de su gentilidad tuvieron los indios, $y$ aun hoy es de grande expectación para el pueblo, es el regocijo y fiesta que llaman del Volador... Los principales papeles de esta fiesta son los cuatro indios que han de volar; y otros cuatro, que como criados suyos se acomodan en las cuatro puntas del bastidor, son los que atan y aseguran de las maromas a los que vuelan, y otro que recoge a el tornillo las maromas, sin que se pise ni muerda la una a la otra, de tal arte y con tanto cuidado asentados en el tornillo, que vienen a quedar como los hilos de una tela en aquel madero donde se recoge la urdimbre, $y$, a éste que asi la acomoda, llaman el mico; y en tal figura de mono se viste y adorna para la representación de la danza y fiesta. Vistense los voladotes con mucha pompa y gala muy extremada, con representación de pájaros en alas de plumas ricas y máscaras representativas de las aves a quienes imitan, muchos chatchigüis, monedas y cascabeles con ayacastles sonoros y ruidosos en las manos. Los otros cuatro criados o sirvientes también se visten y adornan de mucha y costosa gala de vestidos ricos de colores, de las telas de terciopelo, damasco y lana, con muchas diversas plumas y bandas de colores varios, y muchos cascabeles por brazaletes y ajorcas. Vienen éstos con otra mucha tropa de danzantes a la plaza donde es la fiesta y el público teatro de aquella representación festiva, danzando a el son del tepunaguastle y otros instrumentos de flautas y caracoles; $y$, con este aparato y compás de música asientan el sitio y lugar de la música, apartado del Volador algún trecho, de donde a el son de estos instrumentos van saliendo los que han de representar aquel espectáculo, a la verdad digno de verse; y el primero que trepa a el Volador es el que representa el mico, con raras y sobremanera ridículas figurerías, hasta acomodarse sobre el tornillo, donde está entretenido en acomodar las maromas. Luego tras éste van saliendo los indios que han de volar, cada uno con su criado, y se enderezan y caminan para el Volador, subiendo por delante el criado de cada uno a acomodarse en el bastidor, y mientras van subiendo van ejercitando algunas ligerezas y movimientos de la danza; ya allí, mientras los aseguran y prenden de aquellas gruesas maromas, están danzando con suma destreza en lo estrecho y ceñido de aquellas escalerillas por donde suben a lo eminente y empinado de aquel madero..." Véase Fuentes y Guzmán, op. cit., I, 364-366. El RabinalAchi, verdadero drame-ballet y magnífico ejemplar del teatro precolombino, cuya fábula se remonta aproximadamente a la mitad del siglo XIII, es decir, a una época anterior a la fundación del imperio quiché, tiene por argumento la querella entre el principe de Rabinal y el de Queché. Hablan cinco personas en la pieza. Aparecen, además de la reina madre y la esposa de Rabinal-Achi, numerosos guerreros, los disfrazados de águilas y tigres, criados $\mathrm{y}$ danzarines. De los cuatro actos, se concentra la acción en el primero y el cuarto. Hay mucha 
repetición, pues los dos jóvenes caciques se valen excesivamente de las mismas expresiones y frases, $y$, por consiguiente, resulta algo monótono el diálogo del acto prímero. Cuéntase en la fábula la captura del de Queché; su encierro en el palacio del rey Hobtoh; la licencia otorgada al prisionero de gozar de las riquezas de dicho rey; su danza con la princesa, mujer de su enemigo Rabinal-Áchi; la danza guerrera de los tigres y águilas de Rabinal; la despedida del principe de Queché a los valles y las montañas de su tierra; su sacrificio, seguido de otro baile de los guerreros y demás gente. Véase Brasseur de Bourbourg, Rabinal-Achi, Patis, 1862 (Collection de documents dans les langues indigènes, II, 2ème partie).

\section{A New Survey of the West-Indias, etc., pág. 154.}

22 La degollación del Bautista fué un argumento popular del siglo XVI en las piezas religiosas de España y sus colonias. Una (XXV) se halla entre las 96 obras reunidas por Léo Rouanet, Colección de autos, fatsas y coloquios del siglo XVI, Barcelona-Madrid, 1901. En México, asimismo en el siglo XVI, fué representado el Auto de la degollación de San Juan Bautista. Véase Rojas. Garcidueñas, op. cit., pág. 52.

23 Hoy día, en el siglo XX, siguen alquilándose los trajes para las danzas nativas en Guatemala. San Cristóbal y Totonicapán son los dos mercados a que envían los indios por los vestidos. Véase Oliver la Farge II y Douglas Byers, The Year Beater's People, New Orleans, 1931, pág. 100 (Middle American Research Series, núm. 3); Morris Siegel, "The Creation Myth and Acculturation in Acatán, Guatemala", Journal of American Folklore, 1943, LVI, 125; Vera Kelsey y Lilly de Jongh Osborne, Four Keys to Guatemala, New. York, 1939, págs. 287, 297.

24 El baile, designado indistintamente con los nombres de kañal-tce, marimba o venado, y practicado todavía en nuestros tiempos, posee ciertas semejanzas con el descrito por Gage. La Farge y Byers lo vieron como fué ejecu. tado en San Marcos, Guatemala, los días 12 y 13 de abril de 1927, con motivo de la fiesta celebrada en honor del santo patrono del pueblo. Véase op. cit., pág. 100, "Las figuras eran el Viejo y la Vieja, seis cazadores, tres venados, seis monos, un león, un jaguar y seis mujeres. E1 Viejo vestía un sombrero de tres picos con guarnición primorosa, una capa, jubón, calzones guarnecidos con fleco, faja y bandeleto y llevaba un pañuelo ostentoso. Los cazadores estaban vestidos en la misma forma, salvo que tenían zapatos y medias negros. La Vieja y las seis mujeres - los muchachos hacian los papeles de ellasllevaban vestidos más o menos iguales, excepto que a la Vieja le faltaban los zapatos. Llevaban sombreto de alas llanas cubierto de flores artificiales y pedazos de paño, almilla primorosa y falda tiesa que llegaba casi hasta los tobillos, todo muy distinto de lo que visten las indias. Algunos hombres y muchachos desempeñaban los papeles de monos. Llevaban trajes al parecer de origen militar, largos pantalones de color azul oscuro, con anchas listas rojas, chaqueta con cheurrones primorosos e imitaciones de condecoraciones y charreteras. Tenían una gorra puntiaguda y abigarrada y una cola negra que salía debajo de la chaqueta. El león llevaba un traje sucio de color naranja que le cubría de pies 
a cabeza, más o menos igual al pijama que usan los niños. El jaguar estaba vestido de parecida manera, pero el color era de amarillo claro con manchas negras. Los dos tenían cola y corona. Los tres venados estaban vestidos como los cazadores, si exceptuamos la capa magnifiquísima, que en su forma semejaba un poco la piel del ciervo, y la cabeza de cartón duro simulaba asimismo la de dicho animal. En la función de la mañana, las figuras masculinas se disfrazaban con una máscara de cartón. La del Viejo tenía una barba negra, un bigote y el cabello largo y negro; los cazadores eran casi ofensivamente rubios. Las máscaras de los monos, del león y del jaguar eran medianas imitaciones de estos animales. La cabeza del venado, colocada en la coronilla, substituía a la máscara. Cubríase la cara del bailarín con un pañuelo, lo mismo que usaban las mujeres. Ejecutaban el baile, que es universal para todas las ocasiones, conocido comúnmente en español como la zapateta $\mathrm{y}$, en Jacalteca, como el sOñ. Este paso se puede ver practicado en todas partes del sur de México, Yucatán y Guatemala. El Viejo, apoyado en un bastón oficial con puño de plata, ponía una mano en la cadera y bailaba con una cojera reumática que daba el efecto de u'n marinero borracho que hacía el hornpipe. La acción del baile mismo consiste principalmente en evoluciones formales al compás de la marimba y va acompañada irregularmente de la música de sonajas de hoja de lata, llevadas por los danzantes. A intervalos fijos éstos formaban dos filas, frente a frente, y pronunciaban discursos al tenor de que estaban reunidos con motivo de la fiesta en honor de su patrono San Marco. Estas palabras, como lo demás del baile, están absolutamente fijas y escritas en un libro perteneciente al Maestro. Este nos dijo que tales instrucciones, que había conseguido de su predecesor, procedieron originalmente del pueblo de Mazatenango. El oficio del Maestro y otros muchos detalles de la danza evidentemente se remontan hasta los tiempos antiguos... En tanto que sea un drama, representa el hallazgo del venado, que pertenece al Viejo y a la Vieja, y su seguimiento por los animales y los cazadores. En contestación a una pregunta directa, el Maestro convino en que el Viejo y la Vieja corresponden a hitc-mame y hitc-mi [ascendientes de los indios]." Ibid., págs. 104-106. Después del baile de la conquista, el del venado es la ceremonia ejecutada con más frecuencia en los pueblos quichés. Este, lo mismo que el baile del toro y el del tapit, se remonta a los tiempos anteriotes a la conquista. En algunos lugares se funden en una sola ceremonia la fiesta del Palo Volador y el baile del venado. Preside un Viejo llamado Rij Aman, $R i j$ Achi, o José Botones, y una Vieja conocida como Rij Yxoc. Véase S. K. Lothrop, "Further Notes on Indian Ceremonies in Guatemala", Indian Notes, 1929 , VI, $2-5$.

25 Cansalas en el texto A New Survey of the West-Indias, etc., pág. 155.

26. Sonajas.- "Un instrumento rústico, que usan en las aldeas, hecho de una tabla delgada, ancha como de quatro dedos, puesta en círculo y en ella unos agujeros más largos que anchos con igual proporción. En medio de ellos se ponen unos arambres con unas rodajas de azófar, para que dando unas con otras, hagan el son. Manéjase tegularmente con la mano derecha, y dan con ella sobre la palma de la izquierda."

27 A New Survey of the West-Indias, etc., págs. 154-156. 
